\title{
THE CONTRAST BETWEEN THE . BRAIN LESIONS PRODUCED BY LEAD AND OTHER INORGANIC POISONS AND THOSE CAUSED BY EPIDEMIC ENCEPHALITIS*
}

\author{
G. B. HASSIN, M.D.
}

Associate Professor of Neurology, University of Illinois College of Medicine; Histologist, Illinois State Psychopathic Institute; Attending Neurologist, Cook County Hospital

CHICAGO

Brain lesions caused by inorganic poisons, such as lead, are collectively designated encephalitis. The latter term is also used for cerebral lesions caused by infection, such as general paralysis, trypanosomiasis, epidemic encephalitis, Heine-Medin's disease and the so-called enzootic encephalomyelitis of horses (Borna disease ${ }^{1}$ ).

Best studied are the cases belonging to the infectious group chiefly represented by paralytic dementia and epidemic encephalitis. These two morbid entities exhibit such typical interstitial and parenchymatous changes that they deserve to be dignified by the term encephalitis, that is to say, inflammation of the brain tissues. Being essentially alike in their histologic changes, they differ principally in the localization of the lesions which are mainly cortical in general paralysis and mesencephalic in epiclemic encephalitis.

The nonsuppurative cerebral lesions caused by organic or inorganic poisons are somewhat different from the foregoing group, the difference being, in some respects, striking enough to permit a differential diagnosis under the microscope.

This contribution deals with a short review of brain changes resulting from two inorganic poisons-lead and arsenic. The changes produced by lead poisoning have been studied in three cases which were followed up clinically and confirmed by chemical postmorten examinations. The arsenical changes have been studied in photomicrographs and specimens from experimental encephalitis which Dr. A. Jacob of

* From the pathology laboratories of Cook County Hospital, and Illinois State Psychopathic Institute.

* Presented before the first annual meeting of the Association for Research in Nervous and Mental Diseases, New York, Dec. 28-29, 1920.

1. Joest, E.: Untersuchungen über die pathologische Histologie, Pathogenese und post mortale Diagnose der seuchenhaften Gehirn-Rückenmarksentzündung (Bornaschen Krankheit) des Pferdes, Deutsch. Ztschr. f. Nervenheilk. 42: 293, 1911; 44:206. 1912. 
Hamburg produced in monkeys by intraspinal arsphenamin injections. He kindly placed at my disposal some of the stained sections and a great number of his photomicrographs.

Lead poisoning is usually a chronic or subacute disease process, but it seems desirable to contrast the pathologic changes occurring in epidemic encephalitis with those observed in acute lead poisoning. Of the three cases studied two were examples of plumbism in painters, of rather prolonged duration (about ten months), while the third was an acute lead poisoning which, because of unusual clinical phenomena, will be recorded briefly.

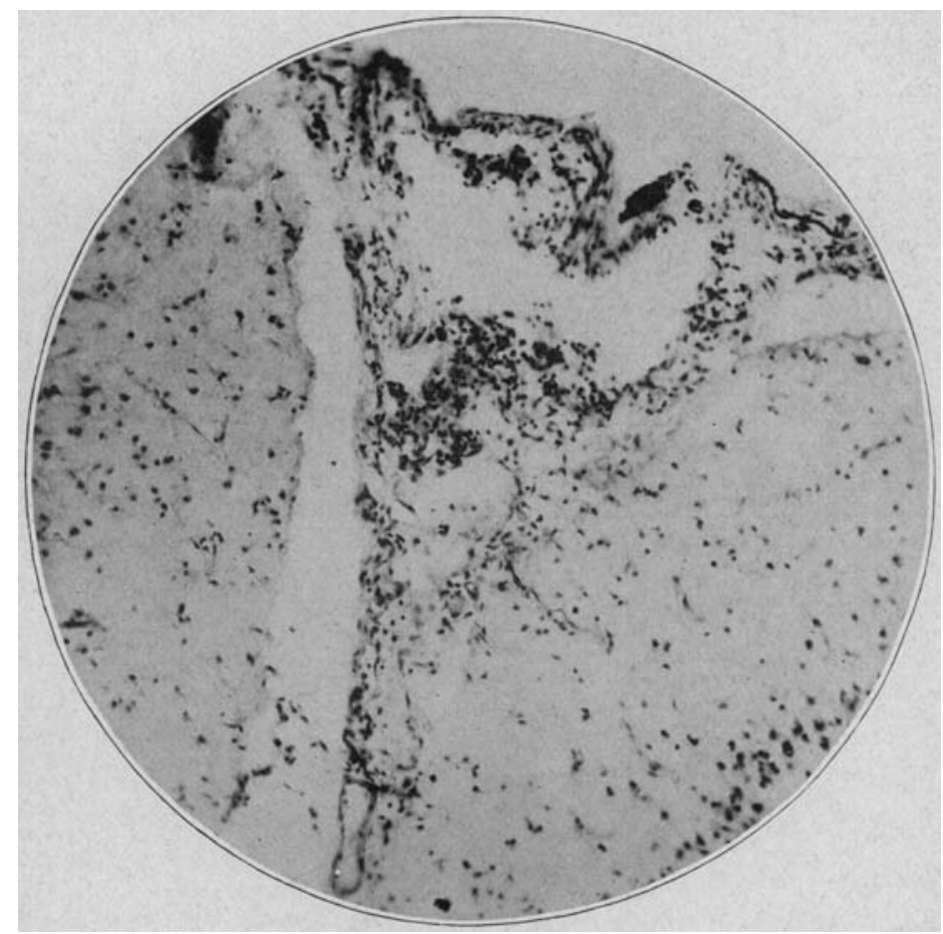

Fig. 1.-Cortex, motor area (lead encephalitis), and pia-arachnoid which is thickened and infiltrated. Some of the infiltrating cells are reproduced in Figure 6 . Toluidin blue; $\times 120$.

\section{CLINICAL HISTORY CF AN ACUTE CASE}

History.-March 29, 1920, a German housewife, 38 years old, mother of five healthy children, was admitted, in a delirious condition, to the neurologic service of Cook County Hospital. It was learned from her husband that she had always been well, had had no miscarriages. had never worked in a factory and presumably had nothing to do with lead. About five weeks before admission she was taken sick with pain in the chest and a cough. A physician prescribed medicine which she expelled by vomiting. She vomited after each 
meal for several days. The vomitus consisted of the food taken and did not contain blood or coffee ground masses. She was in bed for three days. Ten days prior to her entrance to the hospital she was seized with severe abdominal pain, vomiting, excessive thirst, headache and backache. For several days she complained of seeing double, and on the day before admission she became delirious.

Examination.-When admitted to the hospital the patient was disoriented and talked gilbberish with but an occasional understandable phrase. The speech was tremulous, the skin pale, lemon-yellow in color. There was marked pyorrhea, and a characteristic blue line was seen along the edges of the gums.

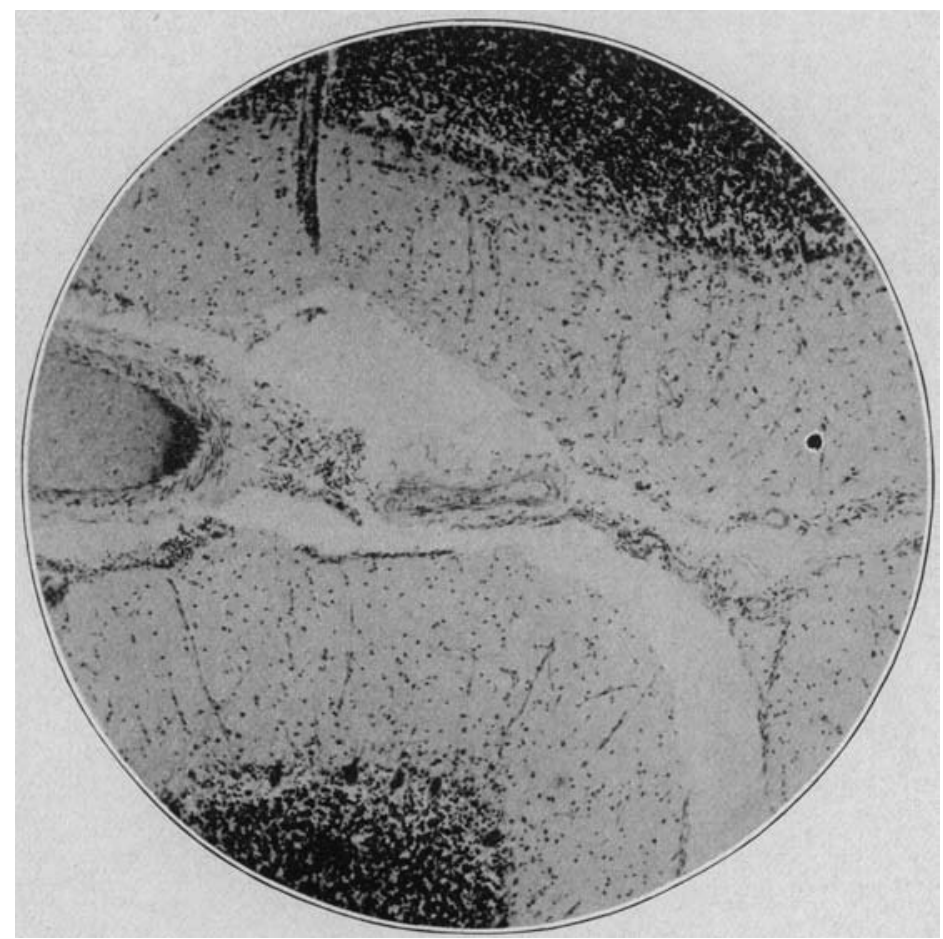

Fig. 2.-Cerebellum and its pial prolongations (lead encephalitis). The molecular layer of the cerebellum shows an alsundance of tender, newly formed vessels and numerous glia cells described in the text; the pia is infiltrated with hematogenous elements shown (partly) on photomicrograph 7. Toluidin blue; $\times 65$.

The tongue was heavily coated and the lips were covered with sordes. Nothing abnormal was discovered in the heart, lungs or abdominal organs. Paralyses, atrophies and trophic skin lesions were absent.

The pupils were equal, irregular and reacted sluggishly to light; there was an occasional nystagmus and a tremor around the mouth during talking. Otherwise the cranial nerves appeared normal. The tendon reflexes were normal; the abdominal reflex was absent; and the plantar reflexes were normal without Babinski or Oppenheim phenomena. 
The spinal fluid was under low pressure, with 112 lymphocytes per cubic millimeter. The Lange and Wassermann tests were negative. The blood gave a negative Wassermann reaction and counts revealed 2,340,000 red cells and 17,900 white cells per culic millimeter: Micro-, macro-poikilocytes and normoblasts were present but no basophilic red cells.

Differential count revealed: small mononuclears 4 per cent., large mononuclears 15 per cent., and polymorphonuclears 70 per cent. The urine was of dark amber color and contained traces of albumin with many granular casts and epithelial cells. The temperature, normal at the time of admission, was

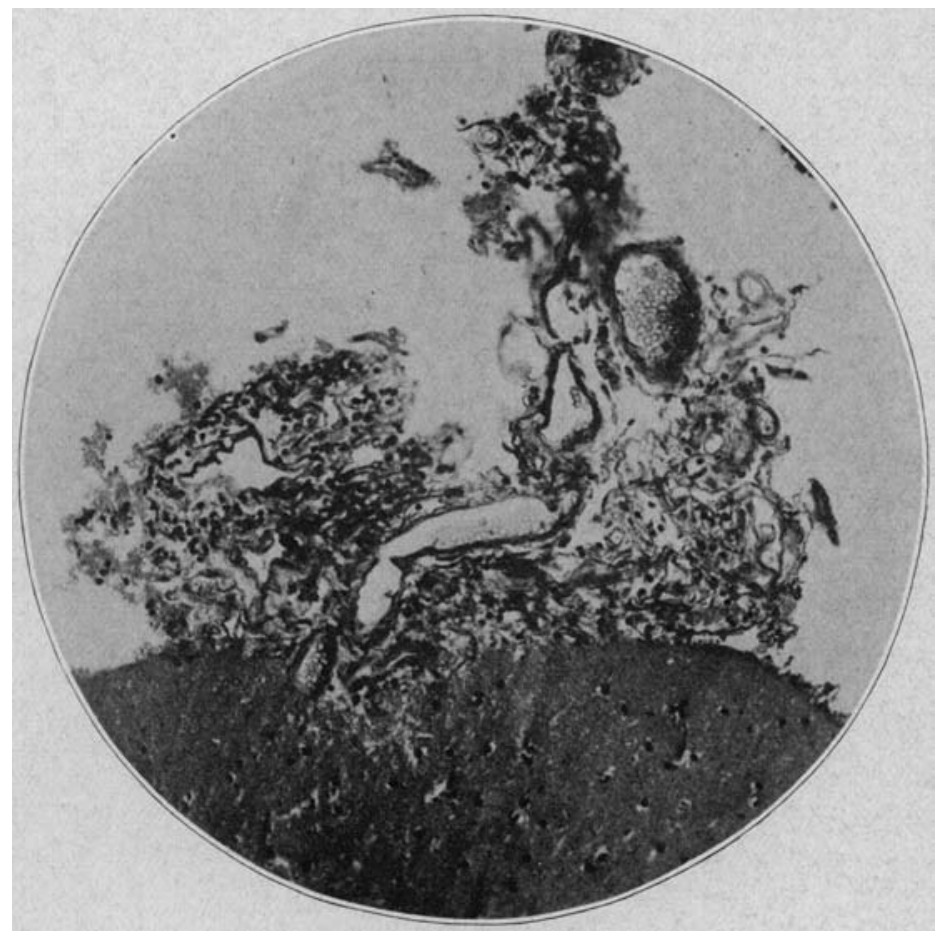

Fig. 3.-Cerelellar pia (lead encephalitis), thickened and hyperplastic with an abundance of vessels and cellular elements. Perivascular infiltrations are lacking. Combined Bielschowsky-Alzheimer-Mann stain; $\times 150$. Compare with Figure 16.

during the patient's four days' stay in the hospital 103 and on the day of her death $104 \mathrm{~F}$.

The main macroscopic findings at necropsy, as recorded by the pathologist of the Cook County Hospital, were: marked so-called lead line of the gums (lead poisoning), marked fatty changes in the liver, icterus, acute generalized emaciation, edema of the leptomeninges, acute simple perityphlitis, hyperemia of the bowels, hyperemia of the gastric mucosa and slight edema of the lungs.

Diagnosis.-The diagnosis of lead poisoning was made during life and was based on the presence of the characteristic lead line on the gums with severe 
abclominal pain, vomiting and anemia. No history of exposure to lead was obtained at first, but later it was learned that "she drank some lead (by mistake?)."

Commont. - Certain features in the clinical history are unusual in lead poisoning, namely, fever, diplopia and sluggish pupils. These symptoms might raise the suspicion of a delirious type of epidemic encephalitis. The fact of lead poisoning, however, appeared to be fully substantiated and the histologic findings, to be described, are identical with those which have been described by others both for experimental and accidental plumbism. They are in no

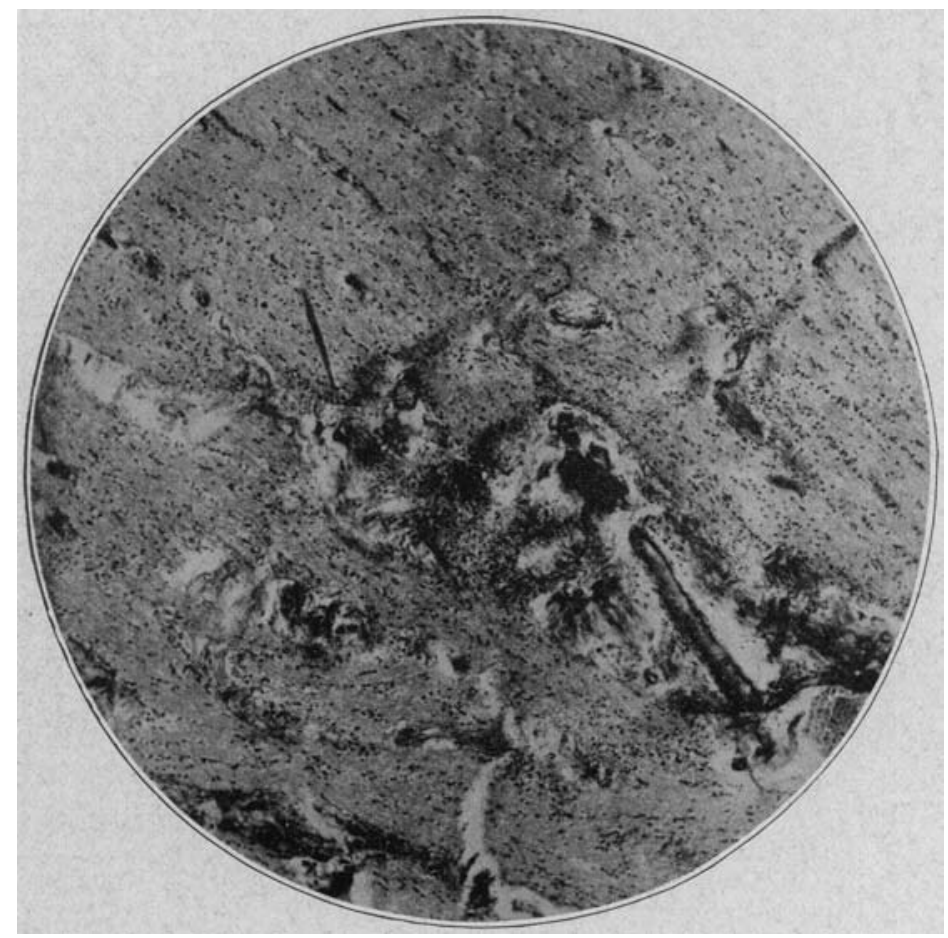

Fig. 4.-Optic chiasm (lead encephalitis). The parenchyma is infiltrated with connective tissue and vessels. Alzheimer-Mann stain; $\times 60$.

way different from those made in the other two cases. The only reason for describing in detail this case in which there might be raised the question of diagnosis is that the poisoning was acute and hence more exactly comparable with epidemic encephalitis. As will be seen from the description which follows, the microscopic changes are entirely different from those of the latter discase. The facts thus afford a striking example of the possibility of differentiating between the two forms of encephalitis by histopathologic studies.

HISTOLOGIC STUDY

The changes described herewith and the illustrations are taken from Case 3 but are identical with those from the two more chronic cases. They correspond 
also with the changes described as lead encephalitis by Mott $^{2}$ and Bonfiglio. ${ }^{3}$

1. Pia-Arachnoid and. Subarachnoid Space.-The pia-arachnoid (Figs. 1, 2, 3 and 4) was thickened and hyperplastic. There were numerous blood vessels and the distended meshes contained many scattered cellular elements, most of them ill defined in character. Present all over the cortex, the pia-arachnoid changes were especially marked on the base of the brain and in the region of the cerebellum and optic chiasm. As seen in Figure 4, the parenchyma of the latter was invaded by large strands of hyperplastic connective tissue, derived from the pia, which consisted mainly of thickened and obliterated vessels. The

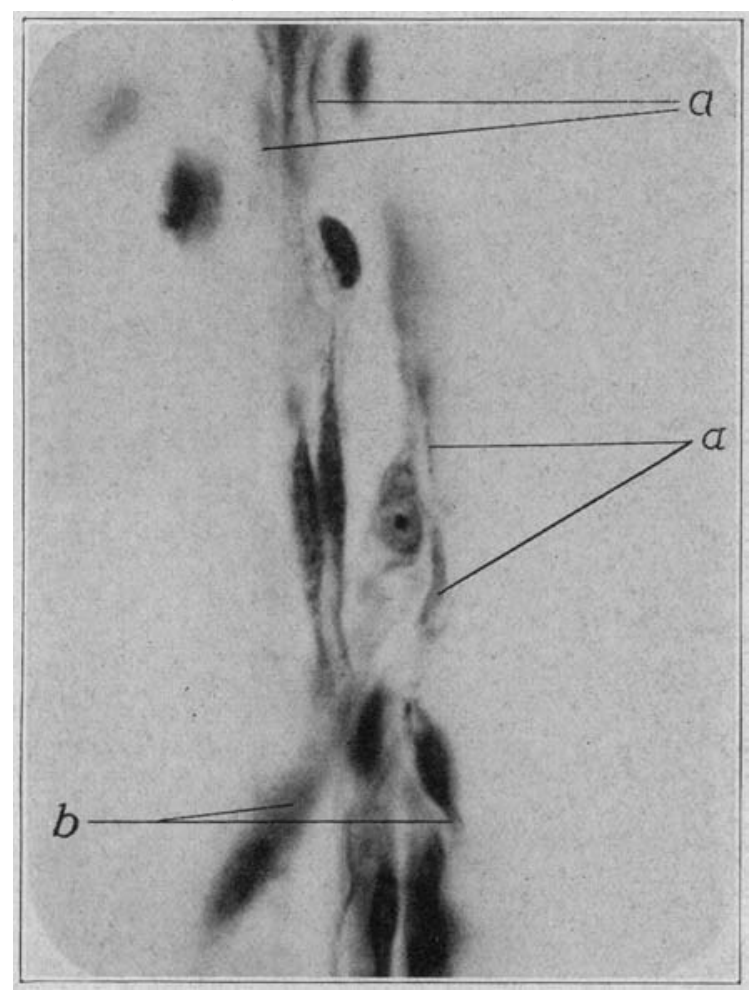

Fig. 5.-Cerebellar pia (lead encephalitis). Proliferated capillaries. Hypertrophy of the endothelial cells, their elongation, the buddings (B) are very marked. A A A, adventitial cells; the rest are endothelial cells. The adventitial spaces, especially to the right, between the adventitial cells (A) and the large endothelial cells are quite marked. Toluidin blue; $\times 1200$.

latter were also quite abundant in the cortical pia and its intracerebral and intracerebellar prolongations (Fig. 3). These revealed a wealth of newly

2. Mott, F. W.: Examination of the Nervous System in a Case of Chronic Lead Encephalitis, Arch. Neurol. \& Psychiat., London 4:117, 1909.

3. Bonfiglio, F.: Circa la alterazioni della cortecia cerebrale consequenti ad intossicazione sperimentale da carbonato di piombo (Encephalite productiva), Nissl-Alzheimer's Arb. 3:359, 1909. 
formed blood vessels and capillaries (Fig. 5) surrounded by proliferated fibroblasts which were frequently packed with greenish or dark granules.

The endothelial cells of the capillaries (Fig. 5) were well developed, hypertrophied, brightly stained and rich in chromatin. Frequently they showed signs of proliferation and budding. There was no perivascular infiltration though there were sometimes numerous cellular elements of various types scattered among the vessels. Many of these cells (Fig. 6) were dark, round and deeply stained and some of them on closer examination showed numerous minute granules and a pale rim of cytoplasm. Some cells were rather broken up and appeared ragged, either freely scattered in the pial meshes or gathered near

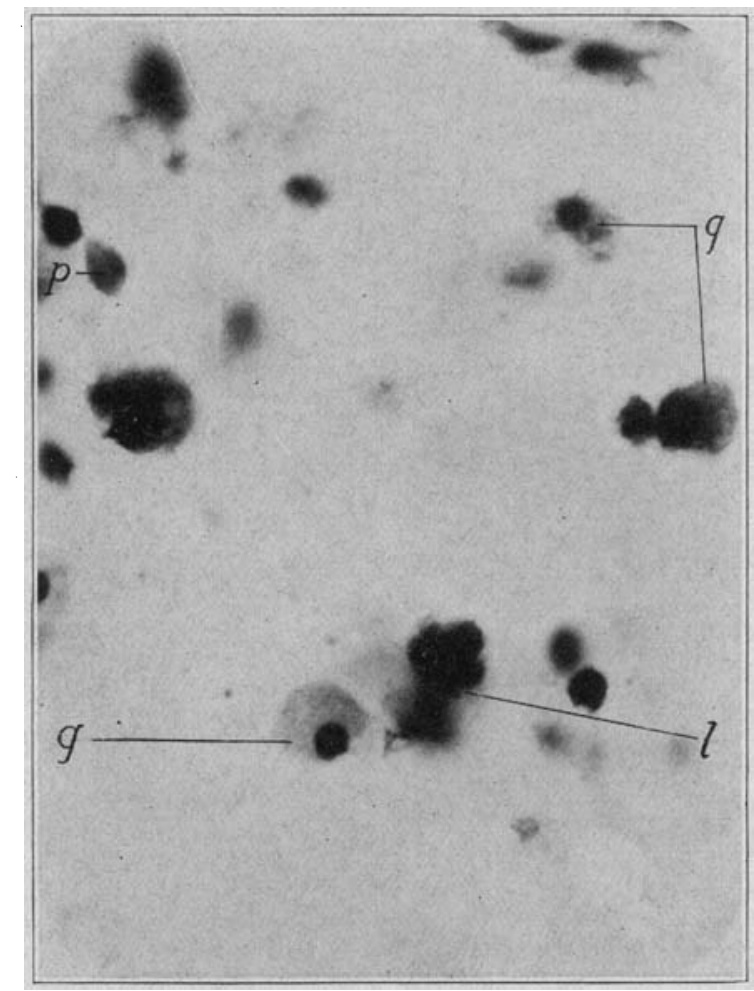

Fig. 6.-Some of the cells of the cortical subarachnoid space (lead encepha1itis). The majority of these are modified lymphocytes. The large reticulated protoplasmic bodies are probably gitter cells; some are degenerated plasma cells, polyblasts and clusters of lymphocytes. P, plasma cells; G G, gitter cells; L, cluster of lymphocytes. Toluidin blue; $\times 1200$.

the blood vessels in the form of clusters. These were evidently modified lymphocytes or plasma cells. In some places they possessed a large amount of homogeneous, metachromatically stained cytoplasm. This, in some instances. appeared granular or reticular, surrounding a pale, oval, eccentric nucleus and the cells thus very much resembled the so-called "gitter" cells. The former type, with homogeneous cytoplasm, may be classified as polyblasts, or large mononuclear lymphocytes. In addition to these three types, lymphocytes, poly- 
blasts and gitter cells, there were a great many fibroblasts, as well as large, oval, pale bodies (Fig. 7, A) containing a few chromatin granules, located singly or in clusters. These were most probably the so-called cover arachnoid cells ("Belegzellen") usually described as mesothelial cells (Weed, Essick). The masses of cellular elements, the abundance of vessels and the distended pial meshes caused the meninges to appear greatly thickened (Fig. 3). On the base, especially around the cerebellum, the foregoing elements were very numerous, sometimes forming dense foci (Fig. 7) consisting of well preserved lymphocytes, plasma cells and many other less typical cell bodies. Such dense foci, however, were present only in the acute case and were much less in evidence in the other two. The foregoing cells did not invade the parenchyma of the cerebellum, as in epidemic encephalitis, but were strictly confined to the pia, its meshes, and the neighborhood of vessels. In the region of the optic chiasm the cellular infiltration was either entirely lacking or comparatively

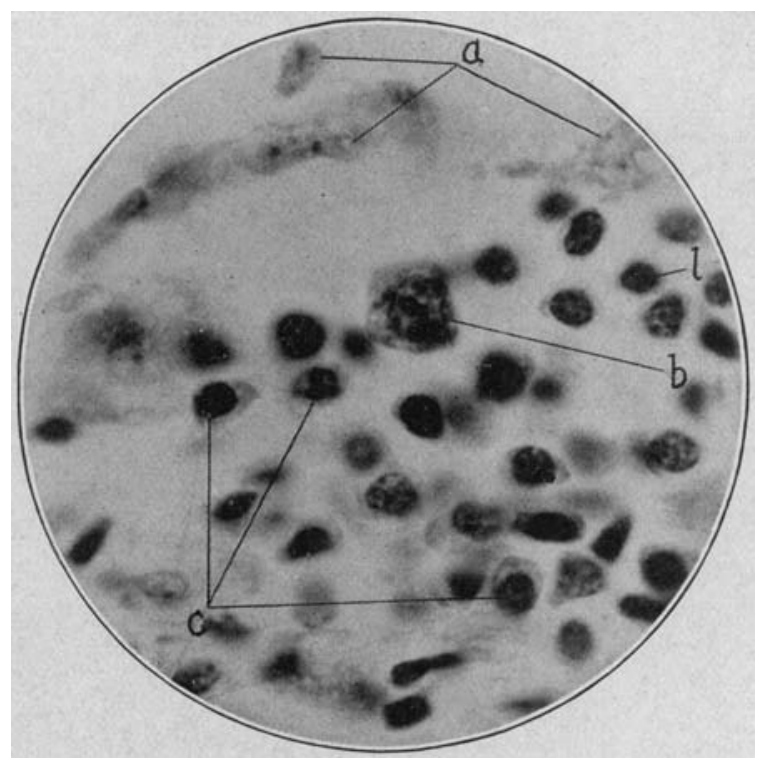

Fig. 7.-Focus of infiltration of the cerebellar subarachnoid space (lead encephalitis). A, mesothelial cells of the arachnoid, hypertrophied; B, large plasma cell; C, smaller plasma cells; L, lymphocytes. Other cells are less well defined. Toluidin blue; $\times 1200$.

mild, being replaced, as noted, by an abundance of connective tissue and vessels which in some places completely obliterated the invaded parenchyma.

In the spinal cord (only the upper cervical portion was available) the subarachnoid space and the pia showed the presence of pigment, lymphocytes and other elements, mostly ill defined.

Summary of Pia-Arachnoid Changes: There were progressive or proliferative changes, especially pronounced on the base of the brain, around the cerebellum and in the optic chiasm. Aside from the marked proliferative or hyperplastic phenomena, there were also present in some areas, especially in the acute case, pure inflammatory changes in the form of infiltration with lymphocytes and plasma cells. 
2. Parenchymatous Changes.-The various regions of the cerebral cortex, the basal ganglions, midbrain and cerebellum have been studied with toluidin blue, thionin, Herxheimer's scarlet red and other methods.

The architecture of the cortical layers in the various regions was well preserved and easily recognized. The subpial zone (stratum zonale) of the cerebral cortex and the molecular layer of the cerebellum (Figs. 1 and 2) were covered with abundant glia cells well supplied with cytoplasm and thin, pale, ramifying processes. Their nuclei were quite large and rich in chromatin, while the ramifying processes could in some instances be followed for a long distance, sometimes even reaching the walls of the capillaries. In the cerebral white substance (Figs. 8 and 9) the glia cells were mostly represented by nuclei, often gathered in rows along the smaller vessels and capillaries. They

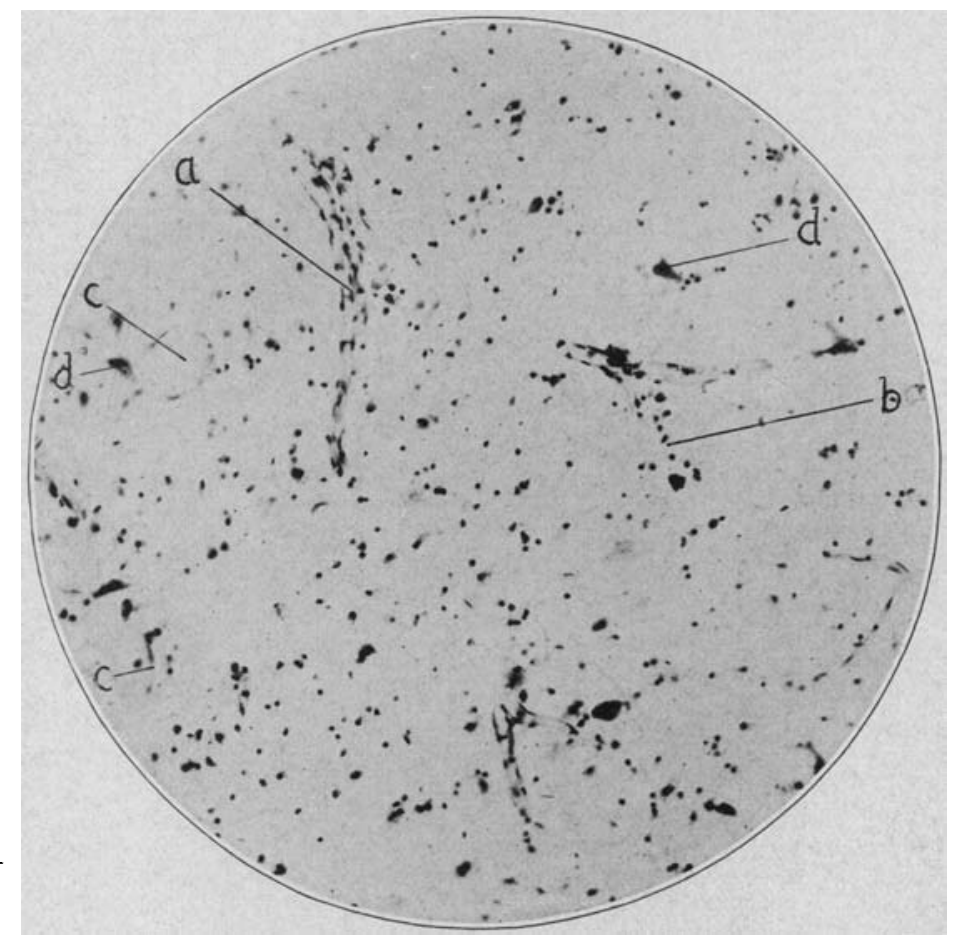

Fig. 8.-Midbrain (region of sylvian aqueduct) fom a case of lead encephalitis. Three prominent capillaries. At A, the upper portion shows two parallel capillaries; at B, a row of glia cells is well marked. The endothelial cells, even in the smallest capillary $\mathrm{C}$, are prominent. D, ganglion cells. The numerous black dots are glia cells in which with the help of a hand lens protoplasm can be seen. Toluidin blue stain; $\times 130$. Compare Figure 14.

were always situated outside the adventitial space and frequently formed clusters. More complicated gliogenous formations, such as myeloblasts, myelophages, and the various types of gitter cells could not be found. Stained with scarlet red, the glia cells sometimes showed fat in the form of minute globules (Fig. 10). In the white cerebral substance the glia cells were numerous, and in some places the glia tissue appeared reticulated. 
The ganglion cells appeared normal, though their processes frequently were diffusely stained and tortuous and could be traced for a long distance. The cytoplasm was homogeneous, often broken up (chromatolysis), the nucleus eccentric with well preserved membrane and chromatin substance.

Some cells, especially those of the deeper layers, were densely surrounded and even invaded by glia cells (satellitosis and neuronophagia). In some areas, for example, the cerebellum, the ganglion (Purkinje) cells showed marked vacuolation (Fig. 11), while in the midbrain the ganglion cell changes were almost lacking. Stained with scarlet red, the ganglion cells uniformly and universally showed the presence of fat in the form of large globules within the cell body and its processes but the nucleus was left intact (Fig. 10)

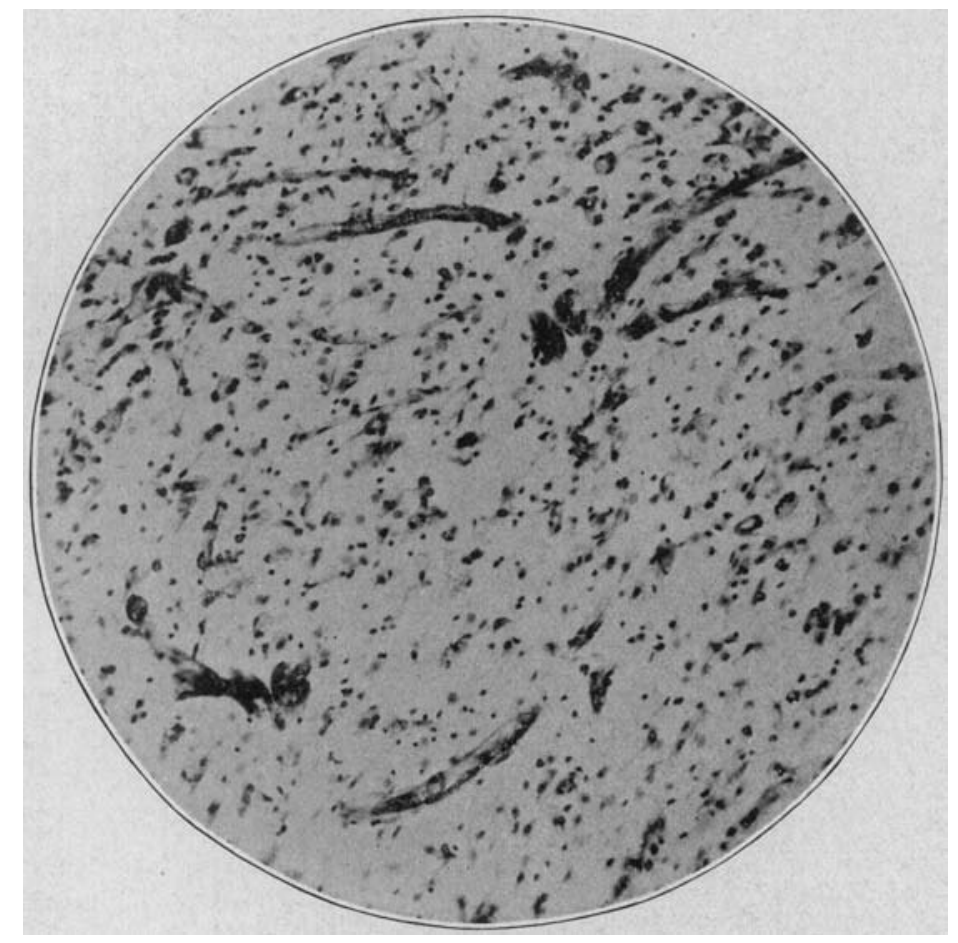

Fig. 9.-Temporal lobe (lead encephalitis). The entire field is covered with an abundance of proliferated blood vessels containing prominent endothelial and adventitial cells. The contrast with Figure 15 is marked. The abundance of glia nuclei is striking. Toluidin blue; $\times 130$.

The nerve fibers of the brain and spinal cord (cervical region), stained with Bielschowsky or Alzheimer-Mann methods, did not appear changed; sometimes they were somewhat thickened and tortuous, especially in the sulycortical area, but there were no signs of degeneration or inflammation.

Summary of Ectodermic Changes: The glia cells, like the pia-arachnoid, showed marked progressive changes; increased size of nuclei, abundance of chromatin and cytoplasmic processes and a great proliferation of glia nuclei gathered in rows or clusters. They usually contained fat and frequently 
invaded the ganglion cells. Most of the latter were well preserved, some showing chromatolytic changes, vacuolation and neuronophagic phenomena.

3. Fascular Changes.-The cortex, subcortical white substance, large ganglions, midbrain, cerebellum, choroid plexus, meninges and spinal cord (cervical region) all showed an excessive vascularization. The smallest capillaries were much in evidence, being usually engorged with blood and exhibiting unusually well stained endothelial and adventitial cells. Some capillaries were exceedingly small and narrow and contained no blood cells, often being represented by a few proliferated endothelial or adventitial cells or by offshoots, buddings or slight protrusions of a vessel wall.

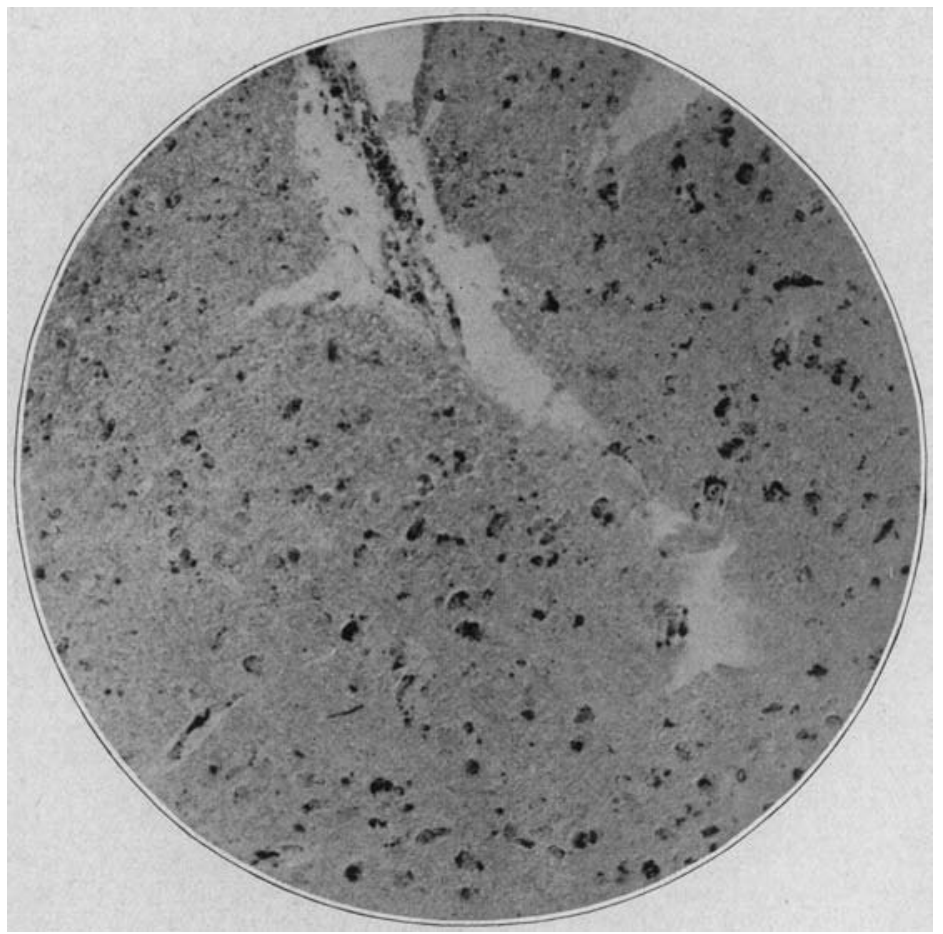

Fig. 10.-Temporal lobe. The ganglion cells, many glia cells, and especially the blood vessel (the upper part of the picture), show fat globules in the form of black spots. Herxheimer scarlet red; $\times 150$.

The appearance of the endothelial cells, rich in chromatin, brightly stained and with cell body elongated as if thinned out, is well shown on the accompanying photomicrographs (Figs. 5, 12 and 13). The budding formations and the endothelial changes, as well as the general appearance of some newly forming capillaries, are especially well seen in Figure 5. Similar, and even more striking, new vessel formations may also be seen in aluundance in the cerebral and cerebellar pial prolongations, in which they are found in every stained specimen. In fact, newly formed capillaries predominate and are much more numerous and conspicuous than fully developed preformed vessels. 
In some smaller vessels and capillaries the adventitial and endothelial cells were distinctly arranged in the form of membranes separated by an adventitial space (Fig. 5) which, however, were nowhere infiltrated. The endothelial, as well as the adventitial, cells were frequently filled with greenish granules; and, as already noted, in the cerebellar pial prolongations they were densely surrounded by lymphocytes, plasma cells and other hematogenous elements.

The walls of the larger vessels were appreciably thickened, the thickening being due to proliferation of the adventitial cells and a great accumulation of fibroblasts, some of which were packed with pigment granules. The endothelial cells, as in the smaller vessels, were either increased in size with a nucleus rich in chromatin or they appeared to have proliferated and formed clusters and buddings.

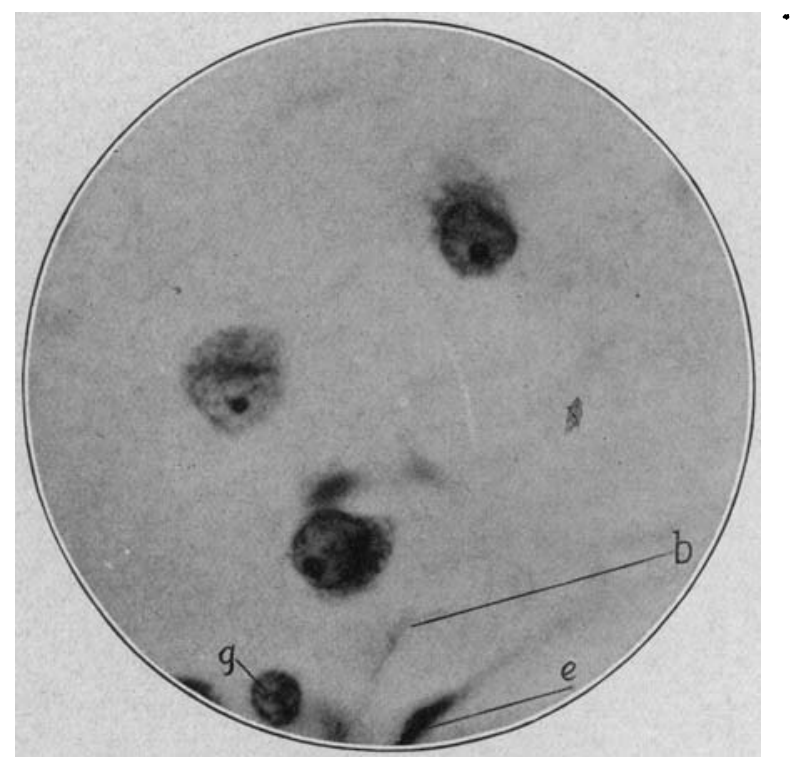

Fig. 11.-Three changed ganglion cells from the cerebellum: the nuclei are eccentric but well preserved. The cell bodies, only partly reproduced, appear pale and vacuolated. Below is a capillary with prominent endothelium (E) and budding (B); near by is a glia cell ( $\mathrm{g}$ ) well supplied 'with cytoplasm. Use a hand lens. Thionin; $\times 1200$.

In the molecular layer of the cerebellum many so-called rod cells ("Stäbchenzellen") were seen. Some of them were sausage-like in shape, as if about to form a capillary, while others had visible processes emanating from a densely stained, chromatin-rich nucleus. These cells were seen only in toluidin-blue or thionin stained specimens and were absent from those stained with the Alzheimer-Mann method. In the latter they appeared as young capillaries or adventitial cells.

Like the capillaries and smaller blood vessels, the larger ones did not exhibit perivascular infiltrations. Neither was the surrounding parenchyma invaded by blood elements (lymphocytes, plasma cells), as is often the case in epidemic encephalitis and general paralysis. 
Figure 8 , for instance, shows the condition of the midbrain in lead encephalitis, while Figure 14 presents the corresponding area in the epidemic type. The latter is densely infiltrated, while the former exhibits only proliferating vessels.

Summary of Vascular Changes: The vessels showed marked proliferative or progressive phenomena, as evidenced by endothelial and adventitial proliferation and newly formed capillaries. Signs of perivascular infiltration, such as is seen in epidemic encephalitis, were lacking.

\section{ARSENICAL POISONING}

The findings described above for the three cases of lead poisoning are exactly similar to those found in the specimens and photographs

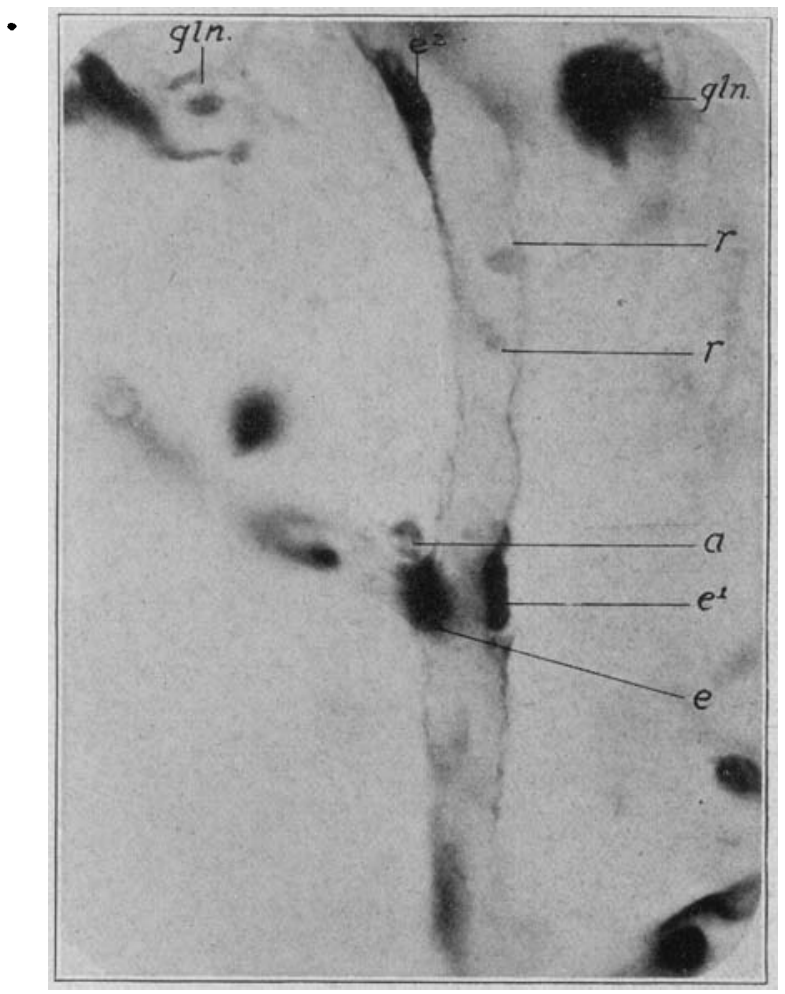

Fig. 12.-Newly formed capillaries from the cerebellar cortex $E E_{1} E_{2}$, endothelial cells; at $\mathrm{E}$ a budding formation is distinctly seen; $\mathrm{A}$, adventitial cell with a cut off process (use lens); R R, red cells; Gln, ganglion cells. Toluidin blue, $\times 1200$.

furnished to me by Jacob, following experimental arsphenamin poisoning in monkeys. These have been described by Jacob, ${ }^{4}$ and therefore need not be further detailed here.

4. Jacob, A., Weygand, W., and Kafka, V.: Klinische und experimentelle Erfahrungen bei Salvarsaninjektionen in das Zentralnervensystem, München. med. Wchnschr. 61:1608, 1914. Die Entzündungsfrage in Zentralnervensystem (Allgemeine Uebersicht), Jahreskurse für ärztliche Fortbildung, May, 1919. 


\section{GENERAL SUMMARY AND DISCUSSION}

The changes produced in the brain tissues by inorganic poisons (lead, arsenic) are both parenchymatous and interstitial.

The former, degeneration of ganglion cells with accumulation of lipoid substances, are essentially regressive or degenerative. The interstitial changes, on the other hand, are proliferative or progressive in

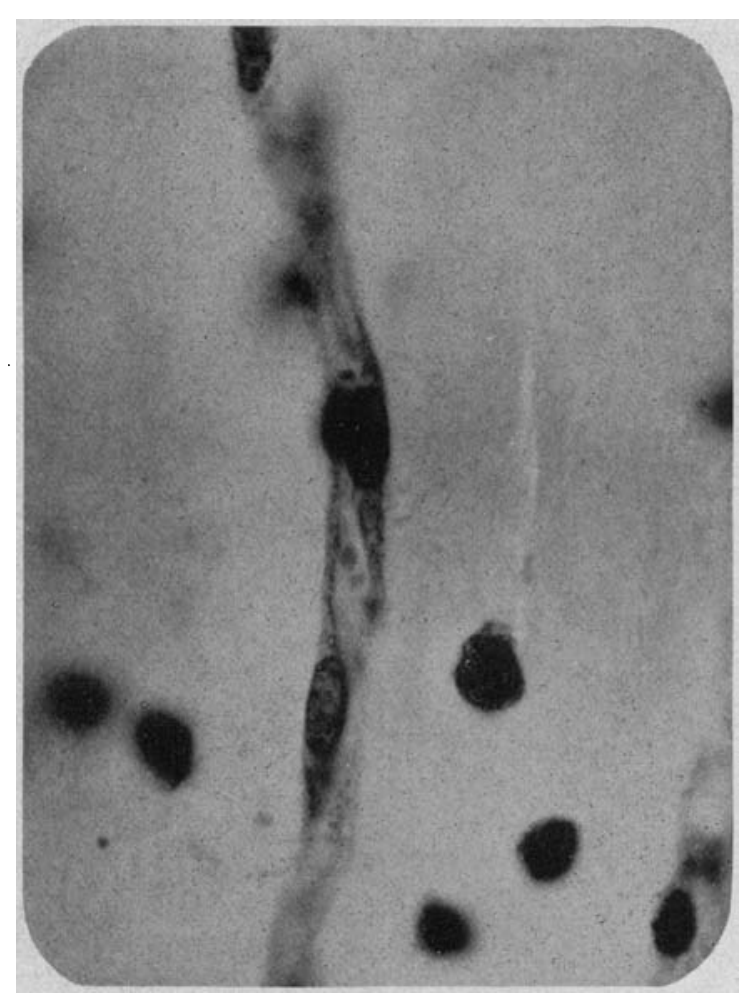

Fig. 13.-A newly formed capillary (lead encephalitis). The vessel is made up of parallel endothelial cells which contain chromatin-rich nuclei with an appreciable amount of cytoplasm at their poles. The cytoplasm is thinned out forming the capillary walls. The dark bodies outside the capillary are enlarged protoplasmic glia cells packed with chromatin. Thionin; $\times 1200$.

character (glia cell proliferation, progressive phenomena in the endothelial and adventitial cells, new formation of capillaries).

While the parenchymatous changes are not peculiar or typical but resemble those to be found in any type of encephalitis, including that of the epiclemic variety, the mesodermal changes of the pia and vessels 
are characteristic and essentially different from those seen in epidemic encephalitis. In the latter, the vascular changes are distinctly infiltrative in character and are only occasionally present in the pia (Figs. 15 and 16).

In lead encephalitis the infiltrative features are either altogether absent or are insignificant; in fact, they are to be found only in acute or peracute cases like the one in the foregoing. Instead, we find marked proliferations in the vessels as well as in the pia-arachnoid. These pro-

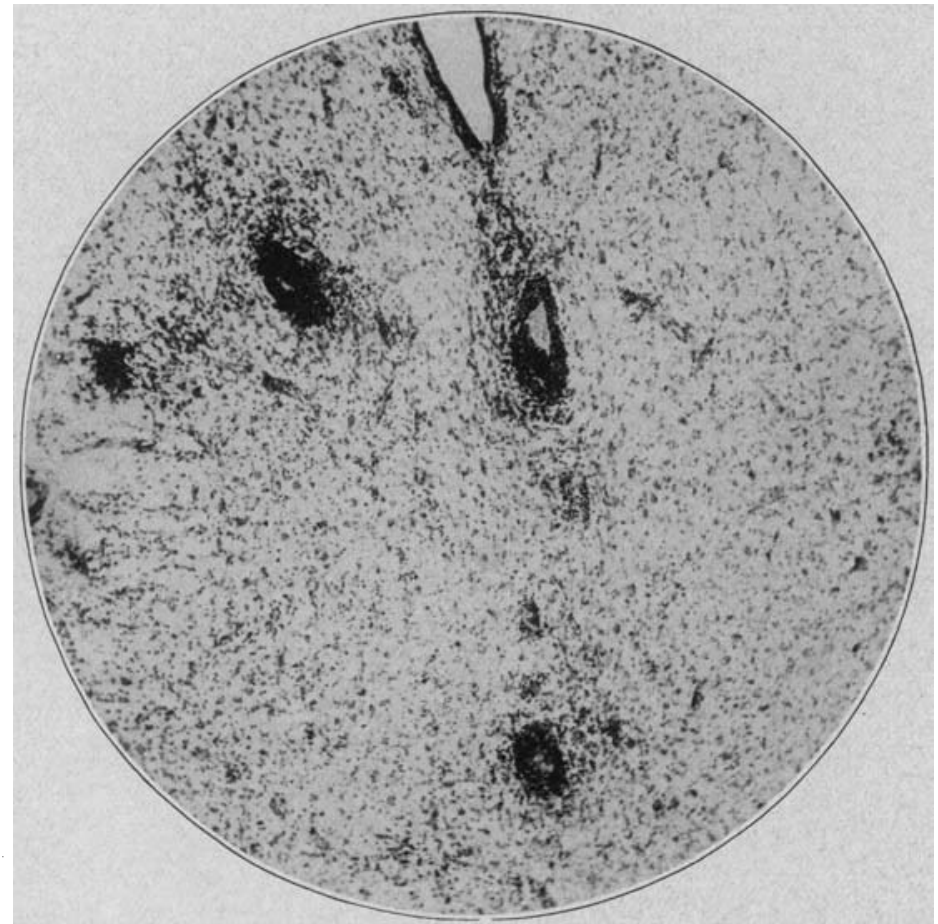

Fig. 14.-Midbrain (region of aqueduct of Sylvius) from a case of epidemic encephalitis. The vessels, as well as the parenchyma, are densely infiltrated with lymphocytes and plasma cells. Compare with Figure 8. Toluidin blue; $\times 65$.

liferative changes are universal but they are especially marked on the base of the brain and around the cerebellum, optic chiasm and temporal lobe. They are comparatively slight in the midbrain. The lesions in epidemic encephalitis, by contrast, always involve, though not exciusively, the midbrain.

The prevalence of productive or proliferative phenomena in experimental lead encephalitis was also noted by Bonfiglio, who suggested for this type the descriptive designation "productive." In contradistinction 
to this, we might label the infections type (to which also belong numerous other forms of nonsuppurative encephalitis caused by various infections, paralytic dementia, Heine-Medin's disease, rabies, pernicious malaria, trypanosoniasis, Borna disease) “infiltrative." It thus seems permissible to claim that vascular infiltrative phenomena are indicative of an infectious type of encephalitis, while the proliferative phenomena denote a toxic condition.

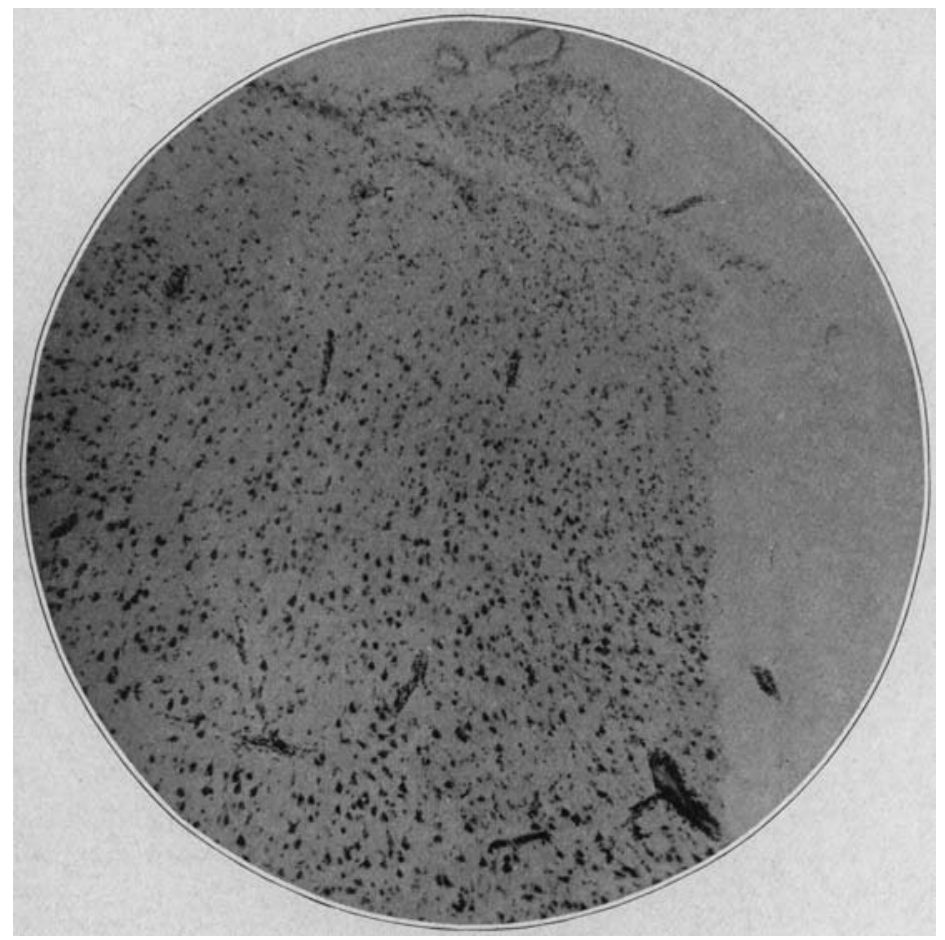

Fig. 15.-Cortex and pia from a case of epidemic encephalitis (Bassoe and Hassin). The pia-arachnoid is mildly infiltrated; the cortex shows a few infiltrated vessels, especially in the deeper layers. Compare with figure 9. Toluidin blue; $\times 50$.

Proliferative and infiltrative phenomena should be sought not only in the endothelial, adventitial and other vascular tissues of the brain proper, but also, and even with greater care, in the pia-arachnoid and the subarachnoid space.

In toxic encephalitis numerous, more or less ill-defined, cellular e.ements are mixerl with mesothelial arachnoid cells, often in the form of clusters. This is not the proper place to discuss the origin and character of the various pial cellular elements, but it may be pointed out that cluster formation or proliferation of the mesothelial arachnoid 
cells is decidedly pathologic, for they represent a reaction against the invasion of the subarachnoid space by some irritating foreign substance. In the case of lead encephalitis this substance is some toxic product. Essick," as well as Weed," distinctly showed that the mesothelial cells react against irritants, such as particulate matter, and are capable of being transformed into new cell bodies resembling macrophages and under certain conditions, old age, for instance, even tumor-like masses ( Need).

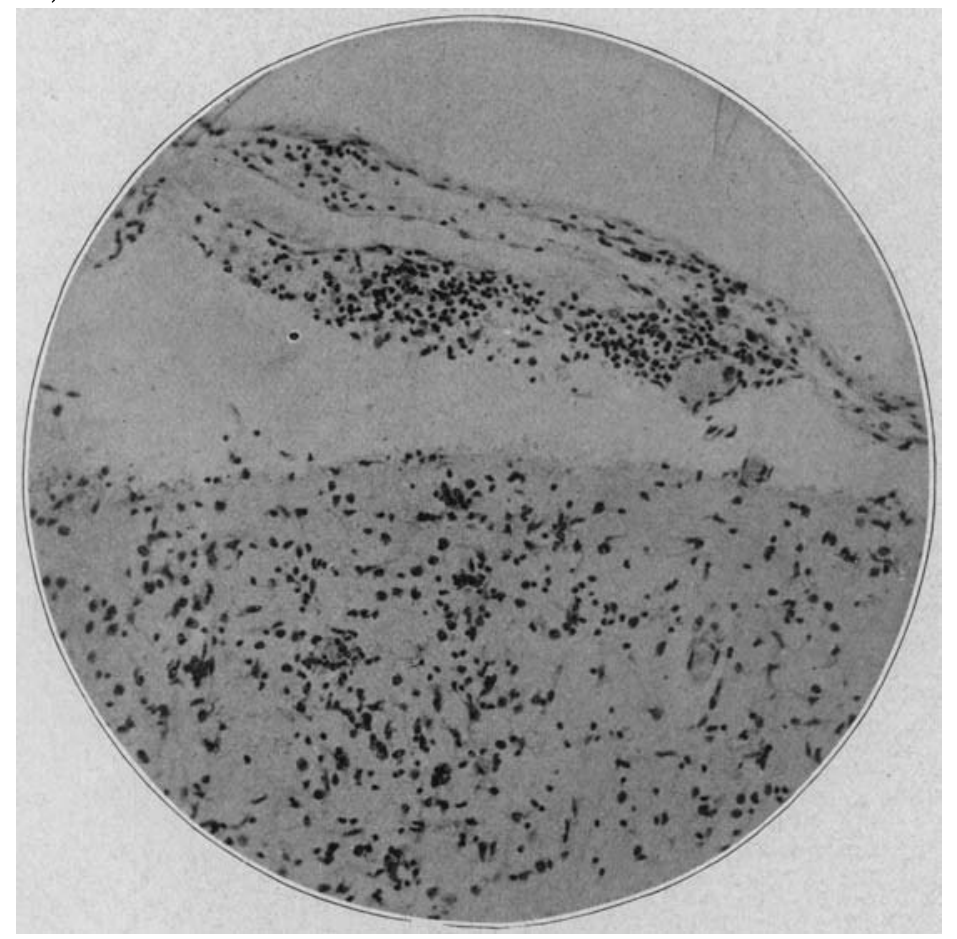

Fig. 16,-.-Cerebellum and pia from a case of epidemic encephalitis (Bassoe and Hassin). The pia is infiltrated, the molecular layer densely covered mostly with hematogenous elements (lymphocytes and plasma cells). Toluidin blue; $\times 150$. Compare with Figure 3 .

The condition of the subarachnoid space and its membranes may thus be considered a valuable standard for the purpose of differentiating various types of brain lesions, whether purely inflammatory, degen-

5. Essick, Charles R.: Formation of Macrophages by the Cells Lining the Subarachnoid Cavity in Response to the Stimulus of Particulate Matter. Contributions to Embryology. No. 42. Publication 272 of the Carnegie Institution of Washington, pp. 377-388.

6. Weed. L. H.: The Cells of the Arachnoid, Bull. Johns Hopkins Hosp. 31:343 (Oct.) 1920 . 
erative or proliferative. In fact, they may show changes even when the brain tissues proper appear quite unaffected.

\section{CONCLUSIONS}

1. The nonsuppurative inflammations of the brain may be divided into two large groups. One, represented by epidemic encephalitis and paralytic dementia, is of infectious origin. Pathologically, it is characterized by excessive, widespread perivascular, and sometimes also parenchymatous, infiltrations, the pia-arachnoid changes being quite mild. This type may also be defined as an infiltrative encephalitis which thus includes all possible direct infections of the brain tissue proper.

2. The second group, mainly represented by lead encephalitis, is due to intoxication and should, therefore, be termed toxic. Pathologically, it shows a great preponderance of proliferative or (as Bonfiglio puts it) "productive" phenomena in the mesodermic tissues (blood vessels, capillaries and the pia-arachnoid). This group may be termed productive encephalitis.

3. Microscopically, it is not only possible to determine whether any given case is one of a nonsuppurative encephalitis, but also whether the encephalitis is due to an infection or to an intoxication.

4. The study of the pia-archnoid and the subarachnoid space is of paramount importance in determining whether the brain is normal or pathologic, for these structures may exhibit changes even when the brain tissues proper appear normal. 